and Tasmania, let us consider the nature of its food in the United States. An examination by Kalmbach and Gabrielson of 2,157 stomachs shows that 57 per cent of the food consists of animal matter and 43 per cent vegetable matter, and of this animal content $4 \mathrm{I} \cdot 55$ per cent is composed of insects. The full details are as follows: weevils 8.50 per cent, ground beetles 5.71 per cent, May beetles $2 \cdot 24$ per cent, other beetles $3 \cdot 14$ per cent, grasshoppers $12 \cdot 41$ per cent, caterpillars 6.04 per cent, millipedes 11.71 per cent, Hymenoptera, Hemiptera, Diptera and other miscellaneous insects 5.93 per cent, animal garbage 1.32 per cent, cultivated cherries $2 \cdot 66$ per cent, other cultivated fruits 1.75 per cent, wild fruits 23.86 per cent, grain $1 \cdot 16$ per cent, vegetable garbage $13 \cdot 57$ per cent.

In Great Britain, we obtain rather different figures: animal food constitutes 51 per cent and vegetable food 49 per cent. Of the former, $26 \cdot 5$ per cent consists of injurious insects, 2.5 per cent of beneficial insects and 3.5 per cent of neutral insects, 8.5 per cent of earthworms, 6.5 per cent of slugs and snails, 1.5 per cent of millipedes, and 2 per cent of miscellaneous animal matter. Of the vegetable food, 20.5 per cent consists of cereals, $2 \cdot 5$ per cent of cultivated roots and leaves, $15 \cdot 5$ per cent of cultivated fruits, 7 per cent of wild fruits and seeds of weeds, and 3.5 per cent of miscellaneous vegetable matter. Summarizing these figures, we find that 36.5 per cent of the starling's food constitutes a benefit to the agriculturist, 41 per cent an injury, and 22.5 per cent is of a neutral nature.

A brief comparison of the figures resulting from the above two investigations shows that in Great Britain the starling has taken to feeding upon cereals and cultivated fruits to a much greater extent than in the United States, and we have little doubt that as this bird increases in numbers a similar change in its feeding habits will take place in America.

There was a time, no doubt, when in Great Britain this bird was a most useful and beneficial one to the agriculturist, just as it is at the present time in Ontario $^{5}$, but once let it reach the high. water mark of abundance, and it becomes equally injurious. It is this fact which we wish to stress, for once this bird reaches the high-water mark it will prove a much more serious pest than the European house-sparrow.

By the enactment of wise repressive measures this calamitous state of things may be averted; but if the situation is not properly realized and things are allowed to drift, then the agriculturists and fruit-growers of the United States will suffer as seriously as, or even more than, those of Great Britain.

Writing in 1912, I stated ${ }^{6}$ : During the first six months of the year the food in an urban district was distinctly of an insectivorous char. acter, and the evidence from the food generally would lead us to place the species amongst those birds beneficial to the agriculturist and horticulturist, but a similar record extending over the same period taken in an agricultural district would, in all probability, reveal the starling as a destroyer of newly sown grain, and extended over the summer months, would show that it inflicts considerable losses upon fruit growers. As the result of further investigations, I was forced to the conclusion that "the starling has become a plague in the land and a source of great national loss".

It is a pity that this undesirable alien was ever introduced into the United States, but that is past history ; what must be looked to at the present is to see that a very careful watch is kept upon this bird from all aspects, and that its numbers be strictly limited. For the information of how this may best be done American citizens may look with every confidence to their famous and unrivalled Department of Economic Ornithology in the Biological Survey.

\footnotetext{
1 Year Book, U.S. Dept. Agric. for 1893, pp. 87-110.

${ }^{2}$ U.S. Dept. Agric., Dept. Circ. No. 336, 1-7 (1925).

${ }^{3}$ U.S. Dept. Agric., Bull. No. 868, 1-66 (1921).

4 Mass. State Bd. Agric., Circ. No. 45, 1-23 (1916).

${ }^{5}$ Lewis, Univ. of Toronto, Biol. Studies. No. 30 (1927).

${ }^{6}$ Second Rpt. Econ. Biol., 1912. pp. 65, 66.
}

\title{
A New Method in Biogeography
}

$\mathrm{T}^{\mathrm{H}}$ HE last two or three decades have witnessed great progress in the studies of ecological and geological factors of distribution of plants and animals, but the results of these studies have had little influence on biogeographers, whose work is still mainly concerned in the parcelling out of the globe's surface into regions, provinces, etc., characterized by statistical ratios of endemic forms and those common to several divisions. The methods of biogeographical work remain generally the same as in the time of Wallace, and a great proportion of literature (zoogeographical in particular) is devoted to discussions of the exact boundaries between formal divisions. When, however, two types of fauna or flora, different in their geological origin and adjusted to different ecological 
conditions, have to develop in close geographical proximity, there can be no linear boundary between them. Their various elements will penetrate more or less deeply into the main area occupied by the other type, this process being usually favoured in the case of one of the types by slow climatic changes in a certain direction. When such changes, for example, favour the spread of forests over a steppe area, some 'islands' of steppe with their characteristic plant and animal population will still remain as evidence of former conditions. Usually, in calculating statistical ratios, such inclusions of alien fauna, or flora, are not distinguished from the elements of the dominating population, which is obviously incorrect.

The need for more careful analysis of populations of geographical areas is better realized by botanists than by zoologists, and modern plant geographers (Braun-Blanquet, Eig, and others) base their analyses on 'phytogeographical elements', and discriminate between continuous distribution of a species, its penetration into a strange area and its 'insular' occurrence in the latter. Zoogeographers, on the other hand, are generally satisfied with the old methods of characterizing the fauna of a country by the full quota of its species regardless to the type of their occurrence, and by drawing line boundaries where, at the best, a more or less broad transitional zone exists in Nature.

Partial attempts to improve on these antiquated methods are not lacking in biogeographical literature, but no definite proposals of a new way of representing distributional facts have been made until the recent paper by Dr. B. K. Stegmann "On the Principles of Zoogeographical Division of the Palæarctis as the Basis of a Study of Types of its Ornithofauna" (Bulletin Acad. Sci. U.S.S.R., pp. 523-563+7 maps; 1936). Dr. Stegmann condemns the idea of mapping zoogeographical divisions separated by line boundaries, and bases his work on the 'types of fauna' which are characterized by the common ecology and past history of their members. The distribution of each type of fauna is to be shown on a map in a special colour, whether it is continuous, or disrupted and 'insular'. Unfortunately, no coloured map is given in the paper (which is only a preliminary one), but a series of black and white maps, each showing the distribution of one type of fauna, is most instructive. Two of these maps are reproduced here (Figs. 1 and 2) in the hope that this will make clear the principle, which is of course very simple.

In the Palæarctis the author distinguishes seven types of bird fauna, as follows:

(1) Arctic type, which has a circumpolar distribution, being connected ecologically with the

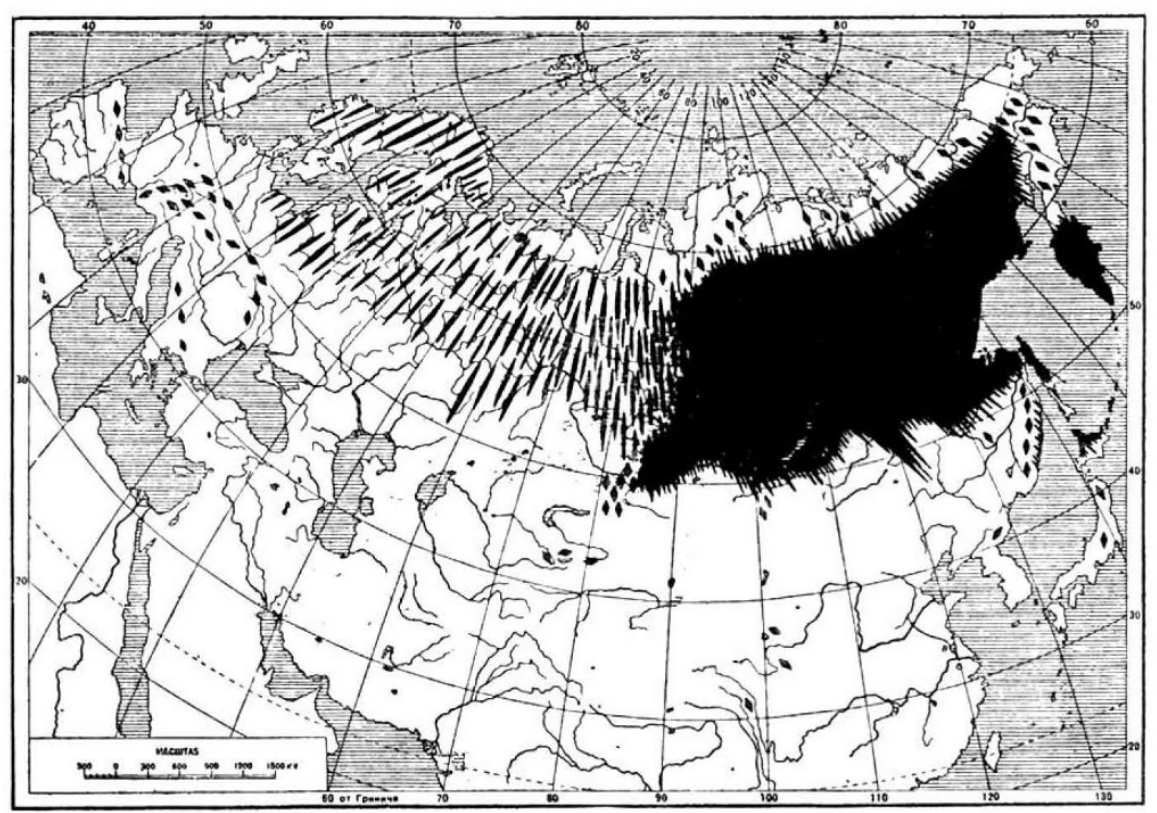

Fig. 1.

Distribution of the Siberian type of faUna.

arctic zone north of the tree limit. Some arctic elements occur discontinuously in the alpine zones of European and Asiatic mountains, so far south as the Pyrenees, the Alps, the Urals, Tarbagatai, Altai, Khankhai and Kentei mountains. They are absent from the Caucasus and Tian-Shan.

(2) Siberian type, or the fauna of taiga (boreal coniferous forests). This populates a continuous area in Eastern Siberia and extends, with gradual reduction in the number of species, to the south Siberian mountains, and those of northern Mongolia, as well as through the northern half of western Siberia into Scandinavia. Some typical taiga birds occur sporadically also in the forests of Central European mountains, in the Pyrenees, in Tian-Shan and even in the mountains of Kansu, Szechwan and Khawin, south-eastern Tibet (see Fig. 1). 
(3) European type, connected with the western European deciduous forests, and extending continuously, but in a gradually narrowing zone, to the southern Urals. Many species belonging to this type penetrate into northern Europe and south-western Siberia, while some occur sporadically in southern Siberia and even trans-Baikalia. The forests of North Africa are also populated by to forests of the Caucasus and Turkestan (see Fig. 2).

(4) Mediterranean type, comprising species connected with xerophilous scrub, steppes and deserts. This fauna populates southern Europe, North birds of European type, and the same applies

south-eastern Asia. It prevails in Japan and China, where it gradually passes into the Indo-Malayan fauna. To the west, this type of fauna extends over the Himalayan forests to Kashmir, a few elements penetrate to Afghanistan and Turkestan, and one even to the Caucasus. Northwards, many Chinese elements extend to Amurland and some even to trans-Baikalia and the Altai; isolated occurrences are recorded so far north as Yakutsk.

It will be seen, even from this very brief summary, that the result of a careful application of the new principle will be either a series of maps, each showing the distribution of one type of

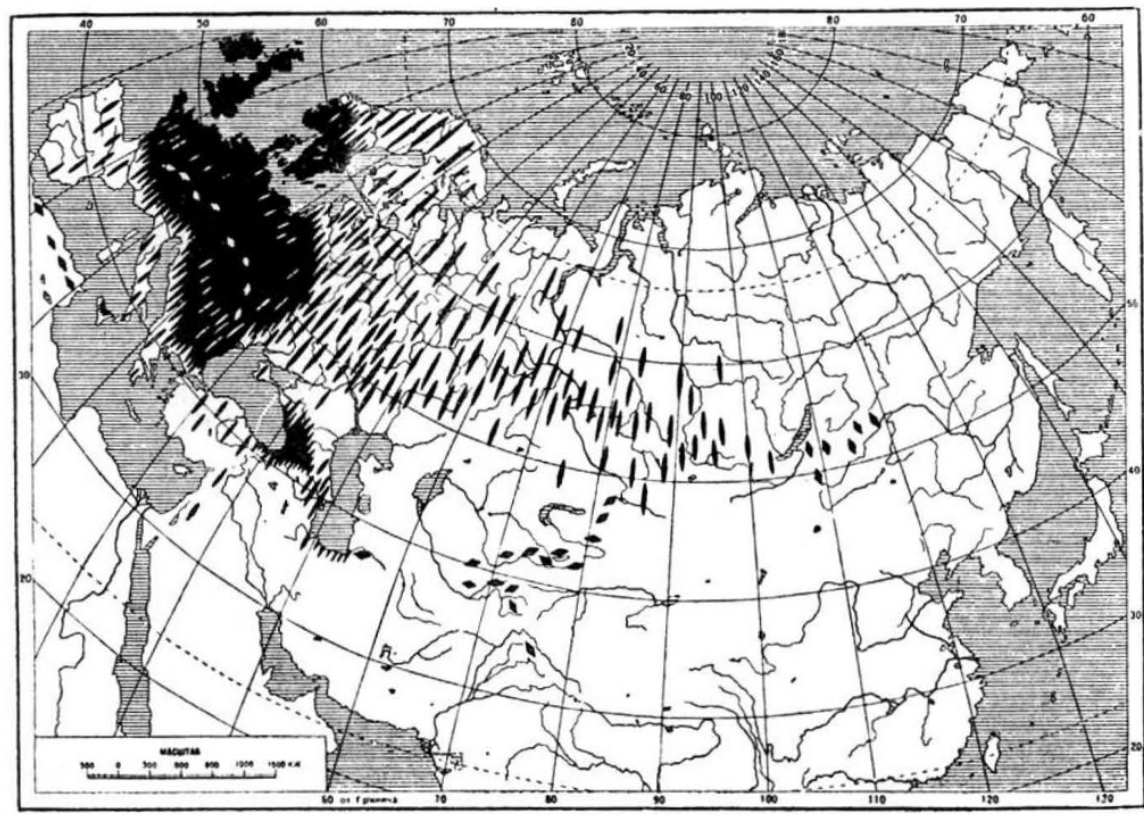

Fig. 2.
Distribution of the EURopean type of FAUNa. fauna (like the two reproduced here), or a composite map in colours showing the great complexity of population of the Palæarctis, and proving the futility of any linear boundaries, since these would inevitably cut across the actual faunistic and ecological connexions and produce a highly artificial picture. There can be no doubt, therefore, that this new method of biogeographical mapping represents a great step towards a more scientific treatment of distributional problems, as compared with the statistical biogeography of the present day. Of course, this type of investiga-

Africa and south-western Asia up to Iran and Afghanistan. Only a few Mediterranean elements penetrate farther east to the Mongolian Altai and Alashan. Northwards, these elements extend to southern England, Germany, the Hungarian plain and the south Russian steppes.

(5) Mongolian type, consisting of species living in the steppes and cold deserts of Mongolia, whence many of them extend into Turkestan. A few Mongolian species occur so far west as Iran, Syria, Asia Minor, Egypt and even northern Africa (two species). In the north they occur in isolated steppe 'islands' in the midst of the Siberian taiga.

(6) Tibetan type, found in the alpine zone of Tibet and the Himalayas and, sporadically, on all high mountains of Palæarctis and even of North America.

(7) Chinese type, consisting of elements ecologically connected with broad-leaved forests of tion requires a thorough analysis of the ecology, phylogeny and past history of each taxonomic group before it can be referred to one or the other faunistic type, but this is the only way to put biogeography on a sound scientific basis.

The difficulties of such work are great and the pitfalls are many, as can be seen even in the example of the paper under review, where the Mediterranean type of fauna obviously includes at least two profoundly distinct faunas, those of the dry Mediterranean scrub and those of treeless deserts. Even in the case of birds, the differences are striking, and this is still more so for other groups of animals. However, this is only a minor fault of the paper, which should mark a new period in the development of biogeography, and deserves the serious attention of zoologists and botanists. 